DOI: 10.46340/ephd.2020.6.4.14
Alla Makarova
ORCID ID: https://orcid.org/0000-0001-7270-0135
Zhytomyr Ivan Franko State University, Ukraine

\section{STRUCTURAL AND PROCEDURAL \\ FUNDAMENTALS OF ACTIVITY: SOCIO-PHILOSOPHICAL ASPECT}

\author{
Алла Макарова \\ Житомирський державний університет імені Івана Франка, Україна
СТРУКТУРНО-ПРОЦЕСУАЛЬНІ ОСНОВИ ДІЯЛЬНОСТІ: СОЦАЛЬНО-ФІЛОСОФСЬКИЙ АСПЕКТ

\begin{abstract}
The article is devoted to the problem of correlation of such components as «action», «act» and "deed» in the activities. A brief review of the existing methodological approaches to their correlation is made and the method of identifying these concepts as methodologically and logically incorrect is denied. It is determined that the act and the action are realized as an activity in the totality of it's ontological features only under the conditions of presentation and qualitative definition of the "goal» and "result» in the activity. Such a universalizing Aristotelian approach is opposed to the Machiavellian one, according to which the basis of activity is the "goal», not the "purpose». The awareness of the reality is defined as the basis for the creation of reality. The provision is considered that the pursuit of purely selfish goals, not aimed at creating a system, does not lead to the creation of activities; the related collision of the effectiveness of totalitarian regimes was revealed, and this collision was resolved through the substitution of purpose and fear as grounds for involuntariness in the basis of totalitarian practice. The concept of action is substantiated, which, unlike the act and action, is based on voluntary value choice and one, thus, can form the activity as a system of conscious, responsible changes. It is suggested that the factors of realization of activity are the connection «(idea) purpose - result - faith - hope - love».

Keywords: act, action, activity, event, deed, purpose, aim, goal, result.
\end{abstract}

Постановка проблеми. Діяльність $є$ категорією, тісно пов'язаною із іншими смислоутворюючими категоріями людського життя, досліджуваними аксіологією, антропологією, етикою. Доки людина не зрозуміє підстав і меж своєї активності, іiі діяльність не буде конструктивною. Не можна судити за окремим вчинком про цілу діяльність або взагалі стверджувати iii наявність. Окремий вчинок - ще не діяльність, але і без вчинку діяльності немає. I це стосується як практики, так і теорії (В. Гілко, Л. Кормич, Е. Гансова)ㄹ. «Етичні дослідження, орієнтовані на урахування цієї різниці, зможуть стимулювати створення комплексу наук, спрямованих на вивчення феномена людини, дадуть можливість вийти за межі того різкого протистояння, яке склалося у XX ст. між аксіологічними, онтологічними, герменевтичними та іншими суто філософськими підходами, з одного боку, та позитивістськими, конкретно-науковими дослідженнями - з іншого. Використання неадекватних критеріїв моральнісної оцінки призводить або до ототожнення, або до протиставлення різних ціннісних вимірів самореалізації людини, що зумовлює неконструктивні форми боротьби ідей. Суперечність між «феноменологічним досвідом» та емпіричним досвідом людини пробуджує необхідність специфічно-людського, духовно-реального самоствердження, протистояння духу «трансцендентальної суб'єктивності» роздріблювальним силам зовнішнього і внутрішнього світів. В контексті різних форм духовно-діяльного об'єднання людини 3 «іншим» (включаючи творення злагоди з самим собою) моральнісне єднання вирізняється щирою героїчною самоцінністю і $€$ вищою формою відповідального ставлення до своєї активності

\footnotetext{
${ }^{1}$ Гілко, В., Кормич, Л., Гансова, Е. (2005). Соціальні орієнтири державної політики. Діагностика сочіального розвитку Одеського регіону. НАДУ при Президентові України; ОРІДУ НДУ, 376.
} 
у світі» - читаємо у монографії «Етос і мораль» ${ }^{1}$ (виділення наше - А.М.). «На порядок денний знову вийшла споконвічна філософська проблема вибору людиною шляху, що веде ії до добра чи зла. Вирішити цю ситуацію нині можливо лише через інновацію людського розуму і моралі» ${ }^{2}-$ визнають автори навчального посібника «Соціально-філософські та етичні проблеми медицини». На нашу думку, саме як шлях потрібно розглядати людську діяльність, як сходження «до чогось», а акти, дії та вчинки як кроки на цьому шляху - кроки вірні та хибні, що заводять на манівці і виводять на путівці, виправдані та невиправдані з огляду на мету і цілі діяльності, які нам уявляються як різні константи.

Ступінь наукової розробки проблеми. Метафоричне і семантичне поле навколо поняття «діяльність»- безмежне. Навіть якщо воно не артикульоване безпосередньо, то стоїть за кожним поняттям антропологічного дискурсу, як його пост-питання i «простір варіантів інтерпретацій». I це ще якщо не зважати на практичні «реалії», а обговорювати діяльність як суто філософський «концепт» або складову певної «парадигми» (Я. Гнатюк) ${ }^{3}$. Тому, аналітичні дискурси синергетичних та ситуаційних методологічних принципів аналізу соціокультурних процесів рівноважливі як частини «методології аналізу суспільства» (Е. Гансова) ${ }^{4}$. Так, наприклад, тема «соціального програмування» (О. Халапсіс $)^{5}$, в якій поняття «діяльності» не на першому плані, принаймні, у його соціально-філософському тлумаченні, все ж актуалізує питання про смисл діяльності, як і тема «соціального прогнозування» (М. Польовий $)^{6}$ та «соціального проектування» (Н. Задорожна, О. Каплун, Т. Кузнецова) ${ }^{7}$. А філософсько-методологічний і соціокультурний смисл поняття «ситуація» незримо, але відчутно окреслює шлях від окремого одиничного до інтегрованого загального і заново ставить питання: «як можлива діяльність?»- і тоді виявляємо, наприклад, що архетипний підхід також дає адекватні методологічні інструменти для відповіді на нього (І. Голубович) ${ }^{8}$. Усвідомлення такого становища утруднює завдання спеціально виділити з кола дослідників «соціального» тих, хто б говорив виключно про «діяльність» без іiї контекстів. Ми можемо говорити про назви їх робіт, але і тут ми отримаємо результат типу: «Иннновационная деятельность» (28 книг), «Инвестиционная деятельность» (77 книг) i т.д. А різниця у смислах українського «діяльність», «дія», «рух», «поведінка», «мета», «ціль» та навіть англійського «action», «activity», «movement», «behavior», «aim», «goal», «purpose» тощо спричинює методологічну колізію «activity» versus «activity» ${ }^{9}$ (Т. Герасимів). Узурпацію наукової сфери аналізу «діяльності» значенням «активність» ми особисто розцінюємо як редукцію, проте навіть за таких умов дослідження цього явища $є$ продуктивними - наприклад, аспекти теми розкривають у своїх працях Ю. Каралаш ${ }^{10}$ Н. Ковтун ${ }^{11}$, О. Сінькевич, М. Титарчук, О. Чумак, Е. Усик та інші.

Метою статті є довести, що діяльність є системою, а не низкою дій та акцій, а єдиним виміром формування діяльності як системи свідомих, відповідальних змін $є$ «вчинок», який базується на добровільному ціннісному виборі, - а не окремий акт чи дія.

Виклад основного матеріалу. Не кожне дослідження діяльності розпочинається із розрізнення понять «активність», «дія», «діяльність», більше того, існують джерела, такі як «Енциклопедія сучасної України», де ці поняття ототожнюються, і від цього подальший текст виглядає дивно. Якщо

\footnotetext{
${ }^{1}$ Аболіна, Т. (2004). Гуманістичний етос моральної культури. Emос і мораль у сучасному світі, 71.

${ }^{2}$ Алексеєнко, А. П., Лісовий, В. М. (ред.) (2010). Соціально-філософські та етичні проблеми медицини. Харків: Колегіум, 5.

${ }^{3}$ Гнатюк, Я. (2020). Парадигмальні методологічні можливості історико-філософської науки. European Philosophical and Historical Discourse, 6 (1), 146-154.

${ }^{4}$ Гансова, Е. (2019).Методологія аналізу суспільства. Наука і освіта, 1, 26-29.

${ }^{5}$ Halapsis, A. (2019). Gods of transhumanism. Anthropological Measurements of Philosophical Research, 16, 78-90.

${ }^{6}$ Польовий, М. (2016). Можливості та обмеження імітаційного моделювання у вивченні історіографії теорії історії. European Philosophical and Historical Discourse, 2 (4), 6-12.

7 Задорожна, Н., Каплун, О., Кузнєцова, Т. (2002). Підхід до проектування систем моніторингу як складової інформаційних технологій підтримки діяльності органів державного управління. Проблемы программирования, $1-2,368-377$.

${ }^{8}$ Голубович, И. (2004). Инварианты и тексты культуры в свете «ситуации человека». Докса, 222-230.

<http://doxa.onu.edu.ua/Doxa6/222-230.pdf>. (2020, November, 12). [in Russian].

${ }^{9}$ Гарасимів, Т. (2016). Поведінка людини: філософсько-правова рефлексія "діяльність" та "активність".

Вісник Національного університету "Львівська політехніка". Юридичні науки, 855, 147-151.

${ }^{10}$ Каралаш, Ю. (2018). Соціальна діяльність та ії роль в сучасних соціальних процесах. European Philosophical and Historical Discourse, 4 (3), 146-154.

${ }^{11}$ Ковтун, Н. (2014). Воля як основа сочіальної активності: теоретико-методологічний аналіз. Житомир: Євенок О. О., 292.
} 
можна погодитися (в загальному) із твердженням, що «словом «діяльність» позначають деяку найпростішу, первинну ланку, з якої складається деякий процес чи дія - механічна, органічна, людська. Діяльність має володіти хоча б деякими ознаками якісної однорідності та відмежованості, щоб можна було ії виокремити» - (очевидно, мається на увазі все ж «дія», а не «діяльність»А.M.), то механіцистське твердження «намагання розглядати процеси як послідовності пов'язаних між собою подій нагадує виокремлення елементів (атомів), які складають фізичні тіла. Серцеву діяльність можна розглядати як низку послідовних дій - скорочень серц. м'яза. Так само деякі різновиди людської діяльності часто розглядають як низку пов'язаних дій - інтелектуальних (мислення), мовленнєвих (мовлення), комунікативних (спілкування) тощо» ${ }^{1}$. Це, на нашу думку репрезентує хибну позицію ототожнення акту та дії, не кажучи вже про діяльність, адже, зовсім не «як низка», а як система не тільки явних знаків, але і прихованих смислів функціонує і мислення, і мова, і комунікація. I часто саме відсутність дії у цій системі парадоксальним чином заміняє дію, що неможливо для роботи серця. Воістину, «из наличного как внешне-данного невозможно объяснить всю человеческую деятельность, здесь есть некая избыточность как раз и характеризующая человеческое-как-таковое, ввиду чего ее задачи полностью не вытекают из биологической сущности нашего вида и тех непосредственных угроз, с которыми он (вид) сталкивается» ${ }^{2}$. Безперервність комунікації ще не свідчить про якість спілкування, хоча дії в їх основі одні і ті ж- а саме, акти як окремі акції. Більше того, з надто великою активністю (кількістю актів спілкування) часто пов'язані відмови від спілкування як на індивідуальному, так і на колективному рівні - починаючи від практики інформаційного спаму до сімейних розлучень на грунті «несумісності переконань».

На нашу думку, для того, щоб з окремих актів склалася дія, 3 дій - подія, а з подій - діяльність мало механічного об'єднання; потрібна:

- внутрішня смислово-ціннісна єдність, що створює якості формування світогляду (у плані мети та результату мислення),

- співіснування у єдиному психо-культурно-семантичному коді діалектів, жаргонів, стилів (у плані мети та результату мовлення),

- створення тем, платформ та організацій для спілкування тощо.

Ми виходимо з того, що кожна діяльність $є$ низкою актів з перетворення світу, але для цього вона повинна базуватися на певній векторній ціннісній спільності; трансформації ж без задуму, ідеї, ідеальної мети ведуть до порожніх трансформацій, які в результаті ланцюга бездумних i безвідповідальних «дій» породжують хаос. Не можна заперечити, що саме задум, ірраціональноідеальна мета надає діяльності такого інтегративного вектору, а розум вже скеровує діяльність як омріяну «систему» у певну структурну стрункість. Ідеал об'єднання як мета об'єднання і створює якість об'єднання (це особливо відчутно в етнонаціональних процесах). Так, акт злуки УНР і ЗУНР неможливий без ідеї злуки, проте сам лише акт, дія або по-дія не буде запорукою стійкої єдності, якщо в задумі, в намірі іiі не було. «В змістовному плані «визначальний образ» світу як прояв творчої сили духу людини являє собою нероздільну єдність об'єктивно значущих ідей, що формуються на його основі (життєве благо, загальне благо, вище благо). Їх смисл осягається інтуїтивно і усвідомлюється опосередковано в ході феноменологічної редукції (психологічної, ейдетичної, трансцендентальної). Онтологічна первинність цього ціннісного підгрунтя зумовлює його безпосередню задіяність в усіх актах діяльно-творчого спілкування людини, проявах високої моральності»- стверджує Т. Аболіна ${ }^{3}, \mathrm{i}$ ми 3 нею погоджуємось. Якщо мислення, мовлення і спілкування розглядати як практичну діяльність, що відрізняються універсалізуючим, спільнотоутворюючим та ідентифікуючим завданнями, то, за Арістотелем, підгрунтям діяльності є не окрема дія, а мета діяльності. «У вченні Арістотеля етика й політика разом, як відомо, становлять єдину галузь практичного знання, практичної епістеми на відміну від теоретичної науки, з одного боку, і творчих, або виробничих (poietikai), знань - з другого. Цьому поділові досить прозорим чином і відповідає ... розрізнення основних способів, або різновидів, людського життя - bios theoreticos («споглядальне життя), bios politicos i також bios apolaystikos («життя, сповнене насолоди») ... спільна належність до царини власне практичного, котре давньогрецький

\footnotetext{
${ }^{1}$ Енциклопедія сучасної України (2020). Дія і діяльність. <http://esu.com.ua/search_articles.php?id=26502> (2020, December, 02).

${ }^{2}$ Халапсіс, О. (2011).Образование и менеджеры будущего. Політологічний вісник. Збірник наукових праць. Київ: IHTAC, 56, 134.

${ }^{3}$ Аболіна, Т. (2004). Гуманістичний етос моральної культури. In Emос і мораль у сучасному світі. Аболіна Т. Г., Срмоленко А. М., Кисельова О. О. та ін. К. Парапан. 70.
} 
мислитель, на відміну, наприклад, від Маркса, розумів, як сказано, у протиставленні не лише теоретичній сфері, а й сфері poiesis'y, тобто творчо-виробничій, котра розглядає і оцінює створений предмет незалежно від майстра-творця і його діяльності. На відміну від мети творчості, зауважує Стагірит, мета вчинку невіддільна від нього самого - «бо тут метою постає саме благо-отримання у вчинку». Така невіддільність предметно-цільової інтенції від самої поведінки, самого способу життя діючої людини і характеризує, за Арістотелем, етику, з одного боку, і політику, з другого» ${ }^{1}$. Так, формування світогляду буде частиною (елементом) процесу мислення, і навпаки; формування діалектів, жаргонів та стилів буде частиною (елементом) процесу формування єдиної мови і навпаки, формування платформ та можливостей для спілкування буде частиною самого процесу спілкування. Якщо ж обрати секуляризуючі, індивідуалізуючі завдання діяльності, тобто практику відділення, розривання з цілим, вип'ячування індивідуально-персонального не як частини, а як самостійної та унікальної реальності, то варто говорити, як Н. Макіавелі, про зовнішню щодо самої діяльності Ціль: «Як зазначає у своїй чудовій монографії про ренесансне викшталтовування індивідуальності Л. М. Баткін, Мак'явеллі в даній галузі «конструює внутрішню форму суб'єкта дії, і це найбільш істотний культурно-змістовий момент його твору» ${ }^{2}$ Дія ж, і ширше й більш відповідно до змісту самого мак'явеллівського трактату, усвідомлена як самостійний смислопороджуючий принцип людського буття, неминуче актуалізує ціле-засобову структуру останнього, причому тим більшою мірою, чим більше сама виступає на передній план, підпорядковує собі життєвий світ і суб' єктивність людини. Попри всю плинність і змінність конкретних людських цілей подібний активізм (надзвичайно виразно поданий, у саму епоху свого зародження, в образі мак'явеллівського політика) робить принципово важливим те одне, що в суб'єкта $є$ ціль (якою

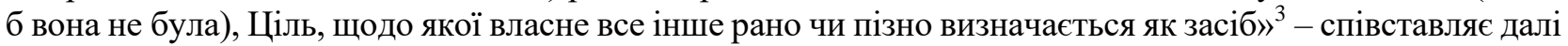
В.Малахов. Так, ціллю мислення як низки актів (акцій) буде вирішення нагальних задач, що з'явилися щойно в реальності; ціллю мовлення буде тимчасове знаходження спільних механізмів опису у ставленні до оточуючої реальності, спрощення процесу передачі інформації; ціллю спілкування стане знаходження тимчасових союзників у вирішенні нагальних проблемних справ тощо. Спільним знаменником таких дій як акцій є їхня вимушеність, ситуативність, а отже, нестійкість, змінність, тимчасовість, що тягне за собою непередбачуваність як фактор обриву діяльності. Адже «процес взаємодії особистості з Іншим базується на свободі вибору кожного суб'єкта... Якщо посередня людина мислить і живе у межах сьогоденної вигоди для свого его, то особистість мислить і діє тривимірно в контексті минулого, сьогодення й майбутнього» ${ }^{4}$. Теоретично жоден 3 подієвих ланцюгів, базованих виключно на отриманні вигоди для окремого его, не стане довготривалим, взаємно добровільним, синергійно-значущим, - не стане діяльністю, обірветься на етапі теперішнього, разом із досягненням Цілі. Цю тезу можна більш-менш виправдано співвіднести із діяльністю однієї особи - індивідуальним виміром, або «випадком» (те, що стоїть поза рядом, ланцюгом), і то при умові, що «довгостроковість» вимірюється «очевидністю». Практично ж така діяльність може тривати доти, доки, по-перше, не виявлена, по-друге, не доведена і по-трете, не покарана (наприклад, окремий злочин). Інколи в силу суб'єктивних обставин дія такого «діяльнісного ланцюга» не обривається достатньо довго. Адже, як випливає із думки Ю. Каралаш, діяльність - В ПРИНЦИПІ довготривалий, стадійний процес: «Повний алгоритм системного розвитку передбачає проходження системою від 1 до 7 станів: 1) передсистемне; 2) фаза розвитку; 3) фаза стаціонарності; 4) фаза розпаду; 5) постсистемне; 6) криза; 7) рух по ієрархії. Проходження системою цих фаз (станів) і $є$ процес системної реалізації (тобто здійснення системи). Так ми підійшли до розуміння діяльності в сенсі, близького до філософського значення руху як змін» ${ }^{5}$.

Разом з цим, постає проблема суголосної поліфонічності і водночас єдності мотивів, коли такий «діяльний егоїзм» реалізується спільнотою. «Найбільш глибинний рівень духовно-моральнісного буття

\footnotetext{
${ }^{1}$ Малахов, В. (2004). «Біос політикос»: нарис етичних проблем. In Emос і мораль у сучасному світі. Аболіна Т. Г., Єрмоленко А. М., Кисельова О. О. та ін. К. Парапан. 8.

${ }^{2}$ Баткин, Л. М. (1989). Итальянское Возрождение в поисках индивидуальности. Москва: Наука, 214.

${ }^{3}$ Малахов, В. (2004). «Біос політикос»: нарис етичних проблем. Етос і мораль у сучасному світі. Київ: Парапан, 17.

${ }^{4}$ Сабадуха, В. (2015). Концепція чотирьох рівнів духовного розвитку людини як методологічне підгрунтя розв'язання проблеми толерантності. «Толерантність як соиіогуманітарна проблема сучасності :

Міжнародна науково-теоретична конференція, 1-2 жовтня 2015 року: матеріали доповідей та виступів. Житомир: Свенок О. О, 51.

${ }^{5}$ Каралаш, Ю. (2018). Соціальна діяльність та їі роль в сучасних соціальних процесах. European Philosophical and Historical Discourse, 4 (3), 140.
} 
людини пов'язаний із сприйняттям життєвих проявів в контексті його «життєвого шляху» як складної відкритої системи, що породжує установку на всеохопну повноту життя. Таке «життя, що спрямоване до блага», є джерелом потреби в «досконалій єдності множинності», яка втілює граничний ціннісний смисл буття людини як духовної істоти. Ця ціннісна першооснова «буття людини в світі» зумовлює впливовість в культурі ототожнення «абсолютного блага» з єднанням. Внаслідок цього у світі об'єктивних духовних ціннісних орієнтацій метафізичне протиставлення і взаємовиключення «блага» i «зла» («єднання» $\mathrm{i}$ «роз'єднання») служить основною моделлю їх співвідношення, тоді як для світу реальних людських відносин такий критерій моральної оцінки є неадекватним» ${ }^{1}-$ констатує Т. Аболіна. Так, теоретично, вчинки нацистів мали б викликати дієвий / активний спротив антинацистів у відповідний, актуальний для тих по-дій час, проте цього не сталося, а відбувся ефект «страждаючих мас» та «поодиноких голосів», що взагалі характерно для тоталітаристських систем. Суспільний егоїзм, що набуває форм колективного фундаменталізму, расизму, тероризму, анархізму, економічних спекуляцій типу корупції, базується, з одного боку, на механізмах свідомого колективного нарцисизму i, з іншого - несвідомих механізмах емоційного зараження, колективного божевілля, який включає як компоненти в тому числі і страх, а отже, все ж базується на недобровільності. Яку саме роль має в цих процесах спільність мотивів чи цінностей, взаємна згода сторін, раціональність чи раціональна співмірність мети і засобів - визначити досить важко. Не виключено, що відбувається включення позасвідомих механізмів саморуйнування, Танатосу на рівні архетипу: «Для осмислення сталості та мінливості соціальних норм треба зважати основу взаємозалежності їх властивостей, а саме: спадкоємність рис організації субстрату руху і прогресивного, і регресивного. Передача певного типу організації - вияв сталості руху і розвитку. Відбувається «передача структури» за ланцюгом причиннонаслідкового зв’язку, яка є нескінченною. Виявів таких структурних особливостей соціуму чимало. Це, наприклад, існування колективного несвідомого (архетипу), відкритого К. Юнгом, яке становить загальний для всіх поколінь психічний образ найбільш еволюційно виправданих форм поведінки; вони втілюються у дійсність, опредметнюються у процесі суспільної практики»². Так чи інакше, а пов'язане з детермінантами діяльності питання відповідальності за вибір «образу дії», а не лише «вчинку» лишається відкритим. Наприклад, мета (ідеологічна програма) комунізму від початків була задекларована як тиранія і викликала, тим не менше, до життя цілий суспільний лад, щоправда, в результаті довготривалої, в тому числі і трагічної ціннісної боротьби (М. Булгаков, «Біла гвардія»). I все ж, така діяльність переважно не оцінюється як «норма». В контексті аналізу дихотомії «свій-чужий» як чинника ідентифікації, М. Козловець зазначає, що «спостерігаються різноманітні модифікації взаємин між «своїм», «чужим» та «універсальним». Ще з античних часів відомий варіант, коли «своє» видавалося за «універсальне». Відтак і варвари сприймалися не просто як інакші, а як такі «чужі», що $€$ порушенням норми «універсального», котрі не досягнули належного розвитку. Звідси і європоцентризм, з позицій якого решта країн, народів і культур постають як ще недорозвинені, такі, що мають реалізувати у своєму поступі ті ж самі засади і схеми розвитку, які вже зреалізувала Європа. Може бути й по-іншому: коли «універсальне» подається як «своє»- один 3 прикладів із нашої нещодавньої історії, коли всі народи колишнього СРСР (а поза його межами - «соціалістичного табору») присилували переживати «радянське» як «своє» (в дійсності, «російське своє»), навіть у випадку, коли його чужість виразно проступала, і народи прагнули встановити контраст до такого «свого» через наголос своєї волелюбності» ${ }^{3}$. Таким чином, позиціонуючись, починаючись як явище ціннісно-інтегративне, насилля переростає в свою справжність саме завдяки зніманню ідеологічних викривленостей, очевидній повній чи частковій невідповідності дій саме як моральних вчинків декларованій меті діяльності і далі утримується на силовій компоненті всупереч моральній незгоді «чужого Іншого» із нав'язаними діями і бажанням, але неможливістю припинити діяльність через страх смерті. Насилля породжує подальше насилля як діяльність тому, що врешті співпадає зі своєю метою, самоціллю, стає сферою автореалізації чистого духу Танатосу замість маскувального рекламного плакату Лібідо. I тоді вже «вчинок» має значення свідомого, а полюси «Свій»-«Чужий» позначають

\footnotetext{
${ }^{1}$ Аболіна, Т. (2004). Гуманістичний етос моральної культури. In Emос і мораль у сучасному світі. Київ: Парапан, 71 .

${ }^{2}$ Гарасимів, Т. (2012) Природні та сочіальні детермінанти формування девіантної поведінки людини: філософсько-правовий вимір. Львів. Львівський державний університет внутрішніх справ, 225.

${ }_{3}^{3}$ Козловець, М. (2015). Дихотомія «свій-чужий» як чинник ідентифікації. «Толерантність як соиіогуманітарна проблема сучасності» : Міжнародна науково-теоретична конференція, 1-2 жовтня 2015 рок : матеріали доповідей та виступів. Житомир: Євенок О. О, 269.
} 
демаркаційні лінії боїв «не на життя, а на смерть», тобто викликають до життя Іншу, опозиційну діяльність, і створюють таким чином явище «гри сил історії», або «міряння силами». Цікаво, що саме подолання суспільного нарцисизму П. Саух вважає не просто діяльністю, а життєдайною стратегією, тобто довготривалою перспективною, орієнтованою на мультефектність та ефективність діяльністю: «Нетерпимість й насильство стали методом практичної дії, яка обумовлює безладдя і хаос, різні форми деградації людини. Зрозуміло, що протистояти цій руйнівній силі може лише ідея ненасильства й толерантності, яка грунтується на визнанні свободи кожної людини, й разом з тим - пов'язаності усіх людей у добрі й злі. Ї̈ практична реалізація, не в останню чергу, залежить від виховання й освіти ${ }^{1} . .$. цінною методологічною стратегією полікультурної освіти має бути викорінення культурно-етнічного нарцисизму, який обумовлює культурно-освітню ізоляцію»² .

Справжня діяльність, в якій дія має значення «вчинку», отже, завжди орієнтована на створення системи, а не на просту зовнішню активність чи дії зі страху. «Природні та соціальні детермінанти формування людини, кожна $з$ яких $є$ абсолютною властивістю людського буття, зовсім не $є$ взаємно байдужими, нейтральними субстанціями, весь зв'язок яких зводиться лише до того, що вони впливають на один суб'єкт - людину, взаємопроникність природного і соціального становлення індивіда. Це - живий і плідний взаємозв'язок, в якому сторони в реальній взаємодії спираються одна на одну, взаєморозвиваються завдяки своєму взаємовпливу» ${ }^{3}$. Метою акції як вчинку має стати усвідомлене створення підгрунтя для створення підгрунтя для наступних акцій, і лише в такому значенні діяльність як ланцюг стає можлива.

Отже, безпосередня спонука (у сенсі примусової безвиході або нагальної вигоди) до дії ще не $\epsilon$ запорукою створення чи, тим більше, успішності діяльності. Підносячи прямий мотив як підставу діяльності, дослідники часто ігнорують віру та надію, як ії основи - надію створити дещо комплексне, життєздатне і життєдайне та віру у власні творчі потенції (Леся Українка, Contra spem spero). Мистецтво «малих кроків», яке символізуватиме в цьому контексті роль окремих акцій та дій, саме по собі, без усвідомлення зв'язки «мета-результат-віра-надія» може стати віддзеркаленням безнадійних механічних спроб створити щось вище, краще, колосальне. 3 іншого боку, діяльність припиниться, якщо для підтримки ії глобального, в багато разів перевищуючого активний (актуальний) ресурс дієвого (подієвого) сценарію не стане засобів; якщо поставлені цілі в результаті виявляться нереальними (нереалістичними). Зневіра та безнадія як причини апатії $\epsilon$ вагомими причинами занепаду і просто соціальної активності, і соціальної діяльності: «Повсякденне насаджування у засобах масової інформації переконання, що людина є слабким об'єктом маніпулювання інстинктивних або економічних чинників призвів у другій половині XX століття до формування нового типу людини, яка зневірилася у власній здатності позитивно впливати на розвиток соціального середовища. Внаслідок цього у сучасному соціумі зростає вплив світоглядних орієнтацій, пов'язаних з запереченням необхідності високого рівня вольової активності людини. На рівні індивідуальної і суспільної свідомості дедалі більше формується переконання щодо існування жорсткої соціальної необхідності, що призводить до виправдання людиною власної безвольності й безініціативності. Під впливом таких уявлень людина втрачає бажання й мужність щось змінювати» ${ }^{4}$.

Висновки. Хоча за Арістотелем мета таких видів діяльності як теоретична (споглядальна) та поетична (творча) лежить за межами суб'єкта діяльності, оцінюється виключно як результат, надважливою в соціальному та суспільному механізмах створення культурної діяльності є система комплексної підтримки ії суб'єктів, - економічна, гуманітарна, правова сітка захисту, та забезпечення не лише задоволення фізичних потреб творців як діячів, а й формування поля надії та віри в успішність (дієвість) діяльності. Це особливо стосується таких сфер як медицина, освіта, волонтерство, орієнтованих на діяльність гуманітарну як спільнотоутворюючу. Тоді до цього незавершеного, а тому недовершеного архетипно-ціннісного триптиху «віри» та «надії» повернеться на своє втрачене місце необхідний компонент «любов».

\footnotetext{
${ }^{1}$ Саух, П. (2015). Толерантність як цінність в системі полікультурної освіти. Толерантність як соціогуманітарна проблема сучасності» : Міжнародна науково-теоретична конференція, 1-2 жовтня 2015 рок : матеріали доповідей та виступів. Житомир: Свенок О. О, 274.

2 Там само.

${ }^{3}$ Гарасимів, Т. (2012) Природні та сочіальні детермінанти формування девіантної поведінки людини: філософсько-правовий вимір. Львів. Львівський державний університет внутрішніх справ, 202.

${ }^{4}$ Ковтун, Н. (2014). Воля як основа соціальної активності: теоретико-методологічний аналіз. Житомир: Євенок О. О, 7.
} 


\section{References:}

1. Abolina, T. (2004). Humanistychnyi etos moralnoi kultury. In Etos i moral u suchasnomu sviti. [Humanistic ethos of moral culture. In Ethos and morality in the modern world]. Kyiv: Parapan, 200 [in Ukrainian].

2. Hansova, E. (2019).Metodolohiia analizu suspilstva [Methodology of analysis of society]. Nauka i osvita. [Science and Education], 1, 26-29. [in Ukrainian].

3. Harasymiv, T. (2012) Pryrodni ta sotsialni determinanty formuvannia deviantnoi povedinky liudyny: filosofskopravovyi vymir: monohrafiia. [Natural and social determinants of forming deviant behavior of human: Philosophical and Legal reflection]. Lviv. Lvivskyi derzhavnyi universytet vnutrishnikh sprav. [Lviv State University of Internal Affairs]. [in Ukrainian].

4. Harasymiv, T. (2016). Povedinka liudyny: filosofsko-pravova refleksiia "diialnist" ta "aktyvnist". [Human behavior, Philosophical and Legal reflection "deed" and "activity"]. Visnyk Natsionalnoho universytetu "Lvivska politekhnika". Serii: Yurydychni nauky: zbirnyk naukovykh prats [Journal of Lviv National University "Lviv Polytechnic". Series: Legal Sciences]. Lviv: Lviv Polytechnic" Publishing, 855, 147-151. [in Ukrainian].

5. Hilko,V., Kormych, L., Hansova, E. (2005). Sotsialni oriientyry derzhavnoi polityky. Diahnostyka sotsialnoho rozvytku Odeskoho rehionu [Social orientation of the state policy. Diagnostics of social development of Odessa Region]: Odesa Regional Institute for Public Administration of National Academy for Public Administration under the President of Ukraine, ORIPA NAPA]. [in Ukrainian].

6. Hnatiuk, Ya. (2020). Paradyhmalni metodolohichni mozhlyvosti istoryko-filosofskoi nauky. [Paradigmatic methodological possibilities of Historical and Philosophical science]. Evropský filozofický a historický diskurz, [European Philosophical and Historical Discourse], 6 (1), 146-154. [in Ukrainian].

7. Holubovych, Y. (2004). Ynvaryanty y teksty kultury v svete «sytuatsyy cheloveka» [Iinvariants and texts of Culture in the light of "Human situation"]. Doksa [Doxa]. <http://doxa.onu.edu.ua/Doxa6/222-230.pdf S. 222-230>. (2020, December, 02). [in Russian].

8. Entsyklopediia suchasnoi Ukrainy (2020) [Encyclopedy of Modern Ukraine (2020)]. Diia i diialnist [Action and activity]. <http://esu.com.ua/search_articles.php?id=26502> (2020, December, 02). [in Ukrainian].

9. Zadorozhna, N., Kaplun, O., Kuznietsova, T. (2002). [Approach to designing monitoring systems as a component of information technologies to support the activities of public administration]. Problemy prohrammyrovanyia [Problems in programming], 1-2, 368-377. [in Ukrainian].

10. Alexejenko, A. P., Lysovii, V. M. (ed.) (2010). Sotsialno-filosofsky ta etychny problemy medyciny [Social-philosophical and ethical problems of Medicine]. Charkiv: Kolegium, 5. [in Ukrainian].

11. Karalash, Yu. (2018). Sotsialna diialnist ta yii rol v suchasnykh sotsialnykh protsesakh. [Social activity and its role in modern social processes]. Evropský filozofický a historický diskurz [European Philosophical and Historical Discourse], 4 (3), 137-143. [in Ukrainian].

12. Kovtun, N. (2014). Volia yak osnova sotsialnoi aktyvnosti: teoretyko-metodolohichnyi analiz. [Will as a basis of social activity: theoretical and methodological analysis]. Zhitomyr: Yevenok O. O. [in Ukrainian].

13. Kozlovets, M. (2015). Dykhotomiia «svii-chuzhyi» yak chynnyk identyfikatsii. [Dichotomy "yours' and other's" as a factor of identification]. "Tolerantnist yak sotsiohumanitarna problema suchasnosti»: Mizhnarodna naukovoteoretychna konferentsiia, 1-2 zhovtnia 2015 roku [Tolerance As a Social and Humanitarian Problem Of Our Time October 1-2, 2015. 4 th International Scientific-Theoretical Conference]. Zhytomyr: Yevenok O. O., 265-268. [in Ukrainian].

14. Malakhov, V. (2004). «Bios politykos»: narys etychnykh problem. In Etos i moral u suchasnomu sviti. [Bios politikos ": an essay on ethical issues. In Ethos and morality in the modern world]. Kyiv: Parapan. 200. [in Ukrainian].

15. Polovyi, M. (2016). Mozhlyvosti ta obmezhennia imitatsiinoho modeliuvannia u vyvchenni istoriohrafii teorii istorii. [Possibilities and Limitations of Simulation in study of Historiography of theory of History]. Evropský filozofický a historický diskurz [European Philosophical and Historical Discourse], 2 (4), 6-12. [in Ukrainian].

16. Sabadukha, V. (2015). Kontseptsiia chotyrokh rivniv dukhovnoho rozvytku liudyny yak metodolohichne pidhruntia rozv'iazannia problemy tolerantnosti. [The concept of four levels of human spiritual development as a methodological basis for solving the problem of tolerance]. «Tolerantnist yak sotsiohumanitarna problema suchasnosti»: Mizhnarodna naukovo-teoretychna konferentsiia, 1-2 zhovtnia 2015 roku: [materialy dopovidei ta vystupiv]. [Tolerance As a Social and Humanitarian Problem Of Our Time October 1-2, 2015. 4 th International ScientificTheoretical Conference]. Zhytomyr: Yevenok O. O., 49-52. [in Ukrainian].

17. Saukh, P. (2015). Tolerantnist yak tsinnist v systemi polikulturnoi osvity. [Tolerance as a value in the system of multicultural education]. «Tolerannist yak sotsiohumanitarna problema suchasnosti»: Mizhnarodna naukovoteoretychna konferentsiia, 1-2 zhovtnia 2015 roku [Tolerance As a Social and Humanitarian Problem Of Our Time October 1-2, 2015. 4 th International Scientific-Theoretical Conference]. Zhytomyr: Yevenok O. O., 273-277. [in Ukrainian].

18. Halapsis, O. (2011). Obrazovanye y menedzhery budushcheho. [Education and "Managers of the Future"]. Politolohichnyi visnyk [Political Science Bulletin]. Kyiv: INTAS, 56, 134-140. [in Ukrainian].

19. Halapsis, A. (2019). Gods of transhumanism. Antropologicheskiye izmerenija filosofskih issledovanij. [Anthropological Measurements of Philosophical Research], 16. 78-90. [in English]. 